\title{
Effect of growth hormone therapy on nitric oxide formation in cystic fibrosis patients
}

\author{
C. Grasemann*,\#, F. Ratjen*,\#, D. Schnabel", E. Reutershahn*, \\ U. Vester* and H. Grasemann**\#
}

ABSTRACT: Airway nitric oxide production is decreased in cystic fibrosis. As growth hormone therapy has been shown to increase nitric oxide production in growth hormone-deficient patients, it may also affect nitric oxide production in patients with cystic fibrosis. The objective of the present study was to investigate the effect of growth hormone therapy on systemic and airway nitric oxide formation in patients with cystic fibrosis.

Nitric oxide metabolites in serum and urine, amino acid concentrations in serum and sputum, as well as exhaled nitric oxide, were measured in children with cystic fibrosis before, during and after 1 yr of treatment with human growth hormone.

Nitric oxide metabolite concentrations increased significantly in serum and urine during the treatment period. Serum amino acid concentrations (including L-arginine, the substrate for nitric oxide synthases) also increased during treatment. The systemic bioavailability of L-arginine for nitric oxide synthases, expressed as ratio of L-arginine/L-ornithine+lysine, remained unchanged. In contrast, L-arginine concentrations in sputum decreased significantly during growth hormone treatment, as did exhaled nitric oxide levels.

Treatment with growth hormone in children with cystic fibrosis decreases exhaled nitric oxide by reducing the concentration of L-arginine in the airways.

KEYWORDS: L-Arginine, hormones, inflammatory marker, pulmonary function

(P) ystic fibrosis (CF) is an inherited disease caused by mutations in the cystic fibrosis transmembrane conductance regulator (CFTR) gene. The clinical course of CF is variable but classically characterised by malabsorption, dystrophy secondary to pancreatic insufficiency, as well as chronic airway infection and inflammation leading to progressive loss of pulmonary function and ultimately respiratory failure [1]. CF airways are deficient for nitric oxide (NO). The mechanisms behind low $\mathrm{NO}$ formation in $\mathrm{CF}$ airways are incompletely understood but may include deficiency of L-arginine, the substrate of NO synthases (NOS), and decreased expression of NOS [2-5].

There is increasing evidence that low NO concentrations are functionally relevant in $\mathrm{CF}$. Positive correlations between exhaled NO fraction $(\mathrm{FeNO})$ and pulmonary function have been repeatedly observed [6, 7]. In addition, gene variants in neuronal NOS (NOS1), which are associated with low FeNO, seem to predispose to a more rapid decline in pulmonary function in $\mathrm{CF}$ children [8]. An increased risk for the colonisation of CF airways with Pseudomonas aeruginosa was also found to be related to NOS1 and NOS3 gene variants associated with low FeNO $[9,10]$.

Conversely, L-arginine supplementation exhibits anti-inflammatory effects, as shown in a rat model of chronic Pseudomonas infection [11] and, when added to the airways, has dilatatory effects on airway smooth muscle in CFTRdeficient mice [12]. L-Arginine may also have protective effects on pulmonary oxidative stress and antioxidant defences [13]. In CF patients, L-arginine supplementation resulted in an increase in FeNO when given intravenously or orally [14, 15], and a single inhalation of nebulised L-arginine has been shown to increase FeNO and forced expiratory volume in one second (FEV1) in CF patients [16].

NO formation can be augmented by increasing the availability of L-arginine and also by increasing NOS expression [17]. Endocrine factors, such as oestrogen, insulin-like growth factor-1 and growth hormone have also been found to modify the L-arginine/NO pathway [18, 19]. Growth hormone is capable of transcriptional activation of NOS [20, 21] and may also affect substrate availability for NOS, as it enhances L-arginine
AFFILIATIONS

${ }^{*}$ Children's Hospital, University of Duisburg-Essen, Essen,

"Dept of Paediatric Endocrinology, Charité University Hospital, Humboldt University, Berlin, Germany.

\# Dept of Paediatrics, The Hospital for Sick Children, University of Toronto, Toronto, ON, Canada.

CORRESPONDENCE

H. Grasemann

The Hospital for Sick Children University of Toronto 555 University Ave Toronto ON Canada M5G 1 X8 Fax: 14168136246 E-mail: hartmut.grasemann@ sickkids.ca

Received:

August 102007

Accepted after revision: November 302007

\section{STATEMENT OF INTEREST} Statements of interest for D. Schnabel and F. Ratjen, and for the study itself can be found at www.erj.ersjournals.com/misc/ statements.shtml 
uptake by the small intestine [22, 23]. Growth hormone deficiency results in decreased systemic NO formation, and replacement of growth hormone in deficient patients leads to increased NO, recovered urinary nitrate and cyclic guanosine monophosphate production, normalisation of elevated vascular peripheral resistance and improved cardiac output [24, 25].

Therapy with human growth hormone (hGH) has been shown to deploy beneficial effects for CF patients, including enhanced growth, weight gain and bone mineralisation [26-28]. Since growth hormone replacement resulted in increased NO metabolism in growth hormone-deficient patients, the current authors hypothesised that growth hormone therapy in CF patients would also result in increased NO formation. Therefore, the effect of hGH therapy on L-arginine metabolism and NO formation was studied in CF patients undergoing hGH therapy as part of a multicentre trial to assess the effect of hGH therapy in CF [26].

\section{MATERIALS AND METHODS}

\section{Study design}

Patients included in the present study participated in a randomised placebo-controlled, multicentre study on the effects of hGH therapy in CF (Pharmacia trial 307 MET-9002026) [26]. Patients were treated with recombinant hGH by daily subcutaneous injection of $0.039 \mathrm{mg} \cdot \mathrm{kg}^{-1}$ body weight per day $\left(\sim 0.11 \mathrm{IU} \cdot \mathrm{kg}^{-1}\right.$ body weight per day), $0.07 \mathrm{mg} \cdot \mathrm{kg}^{-1}$ body weight per day $\left(\sim 0.21 \mathrm{IU} \cdot \mathrm{kg}^{-1}\right.$ body weight per day) or placebo. The study was conducted as a 24 -week double-blind study with a 24-week open-label treatment period. Patients were assigned to one of three treatment arms for 24 weeks. At the end of the double-blind treatment period, patients on growth hormone therapy were maintained on their current growth hormone dosage for an additional 24 weeks, and patients in the placebo group were randomly assigned to either the low- or the highgrowth hormone-dosage treatment regimen. Subjects had to have an established diagnosis of $\mathrm{CF}$, dystrophy defined by a body mass index (BMI) $<10$ th and/or weight $<3$ rd percentile, despite high caloric intake $(>120 \%$ recommended dietary allowance), and a bone age of 8-18 yrs. Exclusion criteria were acute pulmonary exacerbation, diabetes and liver cirrhosis. Patients were studied before initiation of hGH treatment, every 3 months during therapy, and 6 and 12 months after the treatment period.

\section{Study population}

In total, 15 CF patients from a single centre (Essen, Germany), who had all participated in the multicentre study, were included in the present substudy. Of these, 11 patients were treated with hGH for 12 months; six patients with low dose and five with high dose of hGH. Four patients, who were assigned to the placebo group and therefore did not receive hGH for 12 months, were not included in the analysis. Mean (range) age in the 11 patients was $14(12-18)$ yrs, FEV1 was 53 (28-90)\% predicted, and BMI SD score was -1.7 (-3.7- -0.9); these were not different from the total study population [26]. NO metabolites (NOx) were measured in both serum and urine before, during (at 3, 6, 9 and 12 months) and 12 months after hGH therapy. Serum amino acids were measured before and during (6 and 9 months) hGH therapy. Sputum was primarily collected for microbiology. Amino acid concentrations in sputum were measured in five hGH-treated patients able to provide additional samples during the blinded phase of the study (before and after 3 and 6 months) as well as 6 months after hGH therapy. Exhaled NO was measured in all patients before, during (3, 6, 9 and 12 months) and 6 months after hGH treatment. FeNO after 12 months of hGH therapy was only measured in four patients and therefore these data were not analysed.

\section{Serum and sputum sample processing}

Blood was drawn by venous puncture, immediately centrifuged and serum was stored at $-20^{\circ} \mathrm{C}$ until analysed. Spontaneously expectorated sputum was used primarily for microbiology. Additional samples were diluted with buffer 1:1 and vortexed for $2 \mathrm{~min}$, followed by $10 \mathrm{~min}$ of centrifugation at $1,000 \times \mathrm{g}$. Clear supernatant was used for amino acid measurements.

\section{NOx measurements}

Total NO metabolites (nitrate, nitrite and nitrosothiols) were measured after conversion to $\mathrm{NO}$ by using vanadium (III) chloride in hydrochloric acid at $90^{\circ} \mathrm{C}$ with an $\mathrm{NO}$ analyser (NOA 280 and purge vessel; Sievers, Boulder, CO, USA) [29].

\section{Amino acid measurements}

Amino acids were determined by ion exchange chromatography on an amino acid analyser LC 3000 (Eppendorf, Hamburg, Germany) according to the manufacturer's specifications. Serum and sputum samples were deproteinised before analysis.

\section{Exhaled NO measurement}

A chemiluminescence analyser (NOA 280; Sievers) was used to measure FeNO. Single breath on-line measurements for the assessment of lower airway $\mathrm{NO}$ were performed at a constant expiratory flow of $50 \mathrm{~mL} \cdot \mathrm{min}^{-1}$ in accordance with published European Respiratory Society/American Thoracic Society standards [30, 31]. The NO analyser was calibrated before each study with 0 and 185 ppb NO calibration gas (Linde AG, Unterschleissheim, Germany). The mean of three end-expiratory NO concentrations within a variation of $15 \%$ was calculated for each subject.

\section{Statistics}

Data are shown as median (interquartile range). Comparisons of time courses in NOx and amino acid concentrations, as well as FeNO, were performed using the Kruskal-Wallis one-way ANOVA. Comparison of L-arginine bioavailability index (Larginine/L-ornithine+lysine) in serum versus sputum was performed using the Wilcoxon test.

\section{RESULTS}

There was no difference between the low- and high-hGH treatment groups in any of the parameters analysed. Serum NOx concentrations increased significantly $(p=0.027$, ANOVA) during the treatment period and returned to baseline values after hGH was discontinued (fig. 1). Similarly, urine NOx concentrations also increased significantly $(p=0.029$, ANOVA) during treatment and returned to baseline after hGH was discontinued (fig. 2).

Serum concentrations of 18 amino acids measured before and during hGH therapy are displayed in table 1 . With the exception of threonine, mean levels of all amino acids in serum significantly increased during hGH treatment. This 


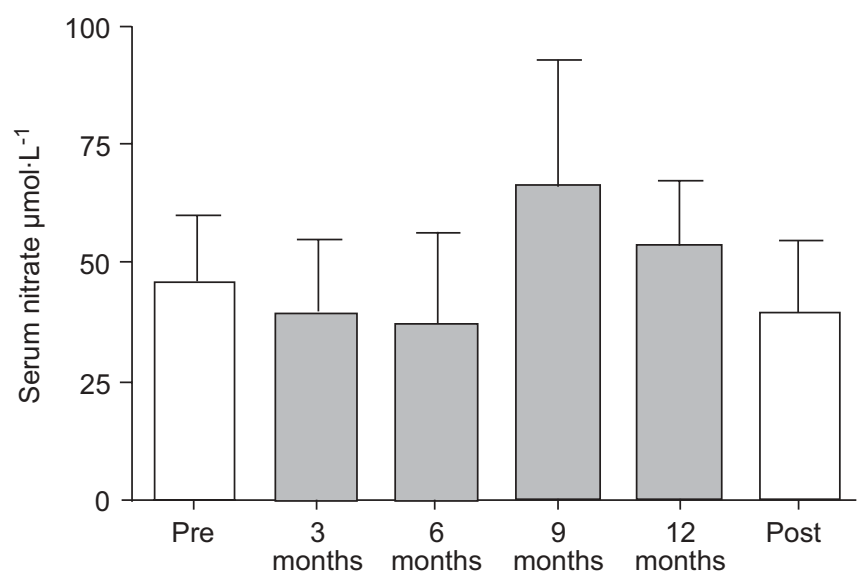

FIGURE 1. Nitric oxide metabolite (NOx) concentrations in serum before during and after 12 months of human growth hormone (hGH) treatment in cystic fibrosis patients $(n=11)$. Serum NOx increased during the treatment period and returned to baseline values after hGH was discontinued.

included L-arginine and L-citrulline, the substrate and the product of NOS activity, respectively, as well as L-ornithine, the product of arginase, and proline, a downstream product of the arginase pathway and precursor of collagen formation (table 1). The ratio of L-arginine/L-ornithine+lysine, which can be used as an index of bioavailability of L-arginine for NOS at a given L-arginine concentration [32], was $0.45 \pm 0.08$ in serum before treatment and remained unchanged during hGH treatment $(\mathrm{p}=0.347$, ANOVA).

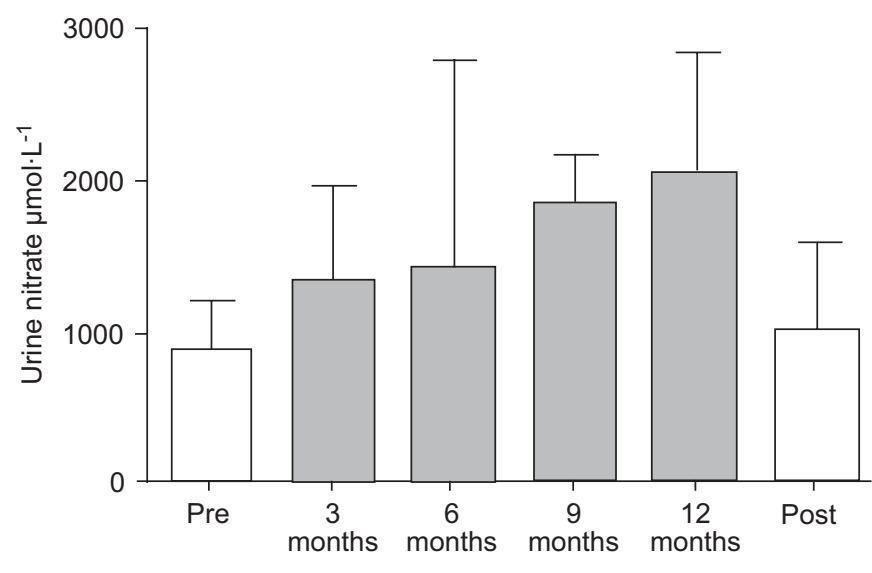

FIGURE 2. Nitric oxide metabolite (NOx) concentrations in urine before, during and after 12 months of human growth hormone ( $\mathrm{hGH}$ ) treatment in cystic fibrosis patients $(n=11)$. Urine NOx concentrations increased during the treatment period and returned to baseline values after hGH was discontinued.

Mean $F$ eNO decreased significantly during the treatment period ( $p=0.005$, ANOVA) and returned to baseline after hGH was discontinued (fig. 3).

L-Arginine concentration in CF sputum was $15.5 \pm 17.3 \mu \mathrm{mol} \cdot \mathrm{L}^{-1}$ at baseline and decreased significantly during $\mathrm{hGH}$ treatment $(p=0.008$, ANOVA; fig. 4a). The L-arginine availability index at baseline was significantly lower in CF sputum than in serum $(p<0.001$, Wilcoxon test). Individual changes in L-arginine bioavailability index in sputum are displayed in figure $4 \mathrm{~b}$.

TABLE 1 Serum amino acid concentrations in 10 cystic fibrosis patients before and 6 and 9 months after the initiation of therapy with human growth hormone

\begin{tabular}{|c|c|c|c|c|}
\hline \multirow[t]{2}{*}{ Amino acid } & \multicolumn{3}{|c|}{ Concentration $\mu \mathrm{mol} \cdot \mathrm{L}^{-1}$} & \multirow[t]{2}{*}{ p-value ${ }^{\#}$} \\
\hline & Pre-treatment & 6 months & 9 months & \\
\hline L-Arginine & $105.6(92.5-127.6)$ & $110.8(100.7-122.3)$ & $138.4(114.1-165.5)$ & 0.027 \\
\hline L-Ornithine & $79.3(54.5-116.9)$ & $75.1(63.2-94.9)$ & $126.0(89.5-135.5)$ & 0.038 \\
\hline L-Citrulline & $24.5(18.0-32.4)$ & $22.7(13.4-25.4)$ & $37.5(27.1-45.7)$ & 0.006 \\
\hline Proline & 166.2 (125.9-242.4) & $148.6(115.7-194.6)$ & $224.6(178.1-254.8)$ & 0.028 \\
\hline Taurine & 137.6 (123.9-166.2) & $172.3(136.5-193.8)$ & $175.8(154.5-203.4)$ & 0.032 \\
\hline Glycine & 280.3 (235.7-403.9) & 343.9 (312.3-410.7) & 436.7 (369.7-485.6) & 0.005 \\
\hline Alanine & $387.8(301.7-450.5)$ & $415.4(365.5-461.0)$ & $469.6(407.7-573.9)$ & 0.042 \\
\hline Valine & $161.1(148.4-187.1)$ & $165.2(145.9-200.8)$ & $237.0(187.2-271.1)$ & 0.006 \\
\hline Phenylalanine & $54.7(40.2-70.9)$ & $51.8(44.3-65.4)$ & 77.5 (67.4-94.9) & 0.013 \\
\hline Histidine & $68.0(57.8-87.9)$ & $75.0(66.6-86.3)$ & $94.4(83.8-109.4)$ & 0.005 \\
\hline Tryptophan & $45.3(35.3-49.6)$ & $40.3(32.8-55.8)$ & $56.3(47.3-64.8)$ & 0.031 \\
\hline Lysine & 134.6 (125.5-205.3) & $131.3(118.3-161.5)$ & 208.6 (151.1-230.9) & 0.018 \\
\hline
\end{tabular}

Data are presented as mean (interquartile range), unless otherwise stated. ${ }^{\#}$ : Kruskal-Wallis ANOVA. 


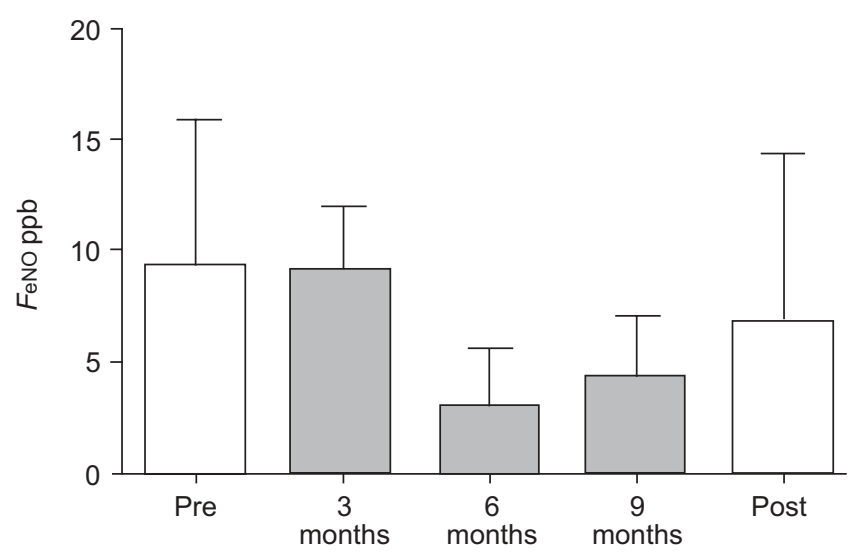

FIGURE 3. Fractional exhaled nitric oxide ( $(\mathrm{e} e \mathrm{NO})$ in cystic fibrosis patients before, during and after 12 months of human growth hormone (hGH) treatment $(n=11)$. Mean $F$ eNO decreased during the treatment period and returned to baseline values after hGH was discontinued.

Although this index decreased in individual patients, the mean sputum L-arginine bioavailability index did not change significantly during hGH treatment $(\mathrm{p}=0.275$, ANOVA).

There was no correlation between pulmonary function data and any of the parameters analysed.

\section{DISCUSSION}

In the present study, treatment of CF patients with hGH resulted in increased serum amino acid concentrations, including L-arginine, the substrate for NO synthases, as well as increased NOx concentrations in both serum and urine. These findings suggest increased vascular or systemic formation of NO during hGH therapy in CF patients and parallel those in patients deficient for growth hormone, where hGH replacement therapy increased systemic NO formation [25]. In contrast, concentrations of L-arginine in sputum as well as exhaled NO levels decreased during hGH treatment, suggesting decreased substrate availability for NOS and decreased NO formation in airways of CF patients treated with hGH.

Increased NO production during hGH treatment, as evidenced by increased NOx in serum and urine, could result from effects of growth hormone on the expression or activity of constitutive or inducible NOS isoforms. Experiments in cultured human endothelial cells had shown that growth hormone resulted in a dose- and time-dependent increase in endothelial NOS (NOS3) gene and protein expression [20]. In a study in cultured mesangial cells, growth hormone treatment was also found to result in a dose-dependent increase in inducible NOS (iNOS; NOS2) transcript [21]. iNOS is of interest in CF because, despite the inflammatory nature of the disease, its expression is decreased in CF airway epithelial cells [3,4]. The mechanisms resulting in decreased iNOS expression in CF are not currently understood but even activation with pro-inflammatory cytokines, which results in profound iNOS activation in non-CF cells, has limited to no effect on iNOS expression in CFTR-deficient cells [5]. Translation of NOS2 mRNA can also be downregulated by low concentrations of L-arginine [33, 34].

Another plausible explanation for higher systemic NOx concentrations in $\mathrm{CF}$ patients treated with $\mathrm{hGH}$ is increased
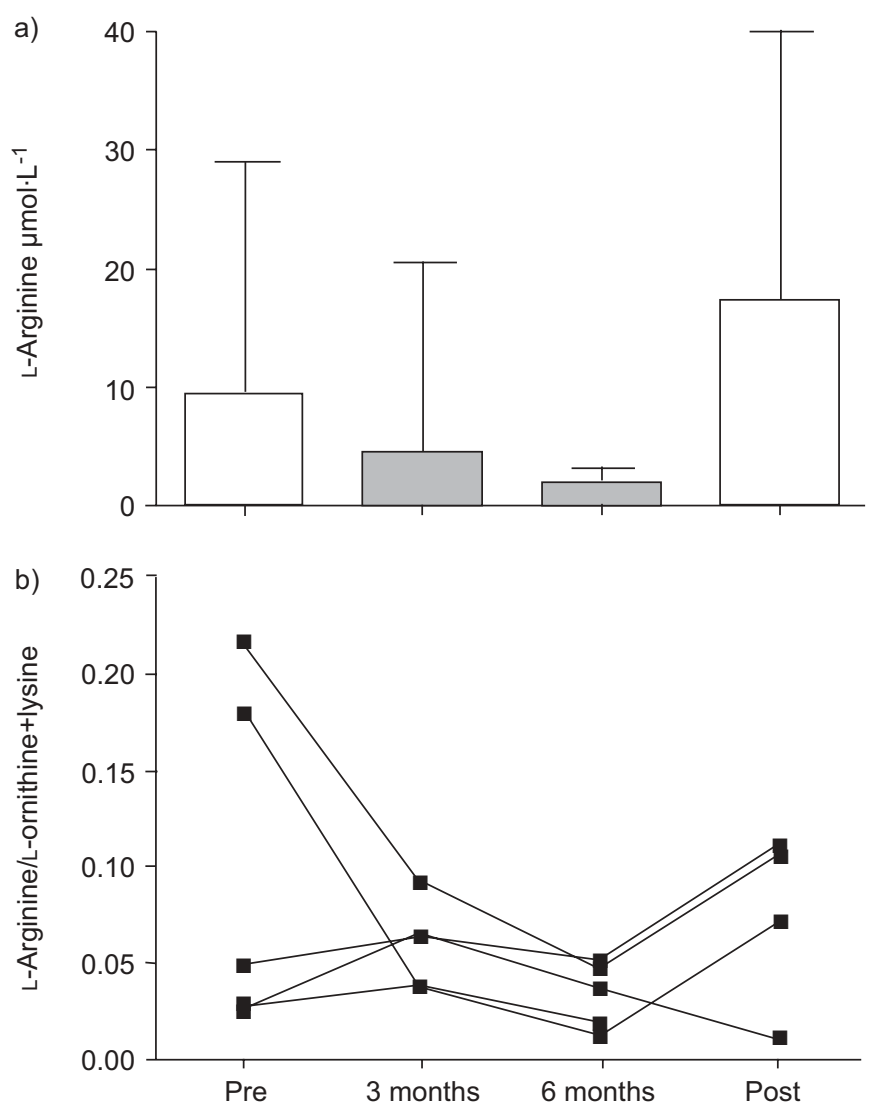

FIGURE 4. a) L-Arginine and b) L-arginine bioavailability index in sputum of cystic fibrosis patients before, during and after 12 months of human growth hormone $(\mathrm{hGH})$ treatment $(\mathrm{n}=5)$. L-Arginine concentrations decreased during $\mathrm{hGH}$ treatment, while the mean L-arginine availability index did not change.

enzymatic NO formation in response to higher substrate availability. L-Arginine conversion by NOS is known to increase with higher extracellular L-arginine levels, although the intracellular concentrations of L-arginine are usually well above the Michaelis constant for NOS. This phenomenon is referred to as the L-arginine paradox [35] and is thought to be responsible for the increase in FeNO in healthy subjects and CF patients supplemented with L-arginine $[14,15]$. Therefore, the observed increase in NOx levels may be directly related to the circulating concentrations of L-arginine, as both L-arginine and NOx increased in serum.

While systemic L-arginine and NOx production increased in CF patients during growth hormone therapy, at the same time NO in the exhaled air decreased. FeNO is used as a surrogate marker for NO production in airways; thus, low FeNO would suggest decreased airway NO production. Alternatively, retention of $\mathrm{NO}$ in airway secretions and conversion to metabolites, such as nitrite or nitrate, could result in low FeNO in the presence of unchanged, or even increased, enzymatic NO production. This mechanism had previously been suggested to be one contributing factor to low FeNO in CF patients $[36,37]$. However, in the present study it was found that treatment with hGH resulted in decreased substrate availability for NOS in CF airways. Although, due to the small sample size, these results need to be interpreted with caution, it was found that not only absolute 
sputum L-arginine concentration, but also the relative bioavailability of L-arginine for NOS, decreased in CF sputum during therapy with hGH. The L-arginine bioavailability index (Larginine/L-ornithine+lysine) reflects the availability of L-arginine for NOS at a given L-arginine concentration, as L-arginine, L-ornithine and lysine utilise the same transmembrane transport system, the cationic amino acids transporter (CAT)-2 [32] for cellular internalisation. This index has recently been shown to be decreased in the blood of patients with asthma, sickle cell disease and CF, and is thought to reflect substrate limitation for NOS-mediated smooth muscle relaxation in these conditions [2, $32,38]$. Even at baseline, this index was significantly lower in sputum compared with serum in CF patients. This reduced Larginine availability for CF airway cells may potentially affect the ability of upregulating $\mathrm{NO}$ as part of a defence mechanism against airway pathogens sensitive to NO-mediated killing, such as mucoid P. aeruginosa [39].

Chronic infection in CF results in neutrophil-dominated inflammation and increased concentrations of inflammatory markers in the airways [1]. However, activation of signal transducer and activator of transcription (STAT) 1 is reduced in $\mathrm{CF}$, and the interferon (IFN)- $\gamma$ signalling pathway, which involves STAT1 and leads to NOS2 gene induction in airway epithelial cells, is defective in CF [40]. Therefore, inhibitory effects of growth hormone on these pathways may further decrease the expression of NOS2 in CF. Indeed, growth hormone was found to suppress the synergistic induction of iNOS by the cytokines IFN- $\gamma$ and tumour necrosis factor- $\alpha$ in a rat insulin-secreting cell line (INS-1 cells). This effect was thought to be mediated through inhibition of IFN- $\gamma$-activated STAT1 by growth hormone [41]. In contrast, iNOS enzyme activity in liver tissue from calves undergoing lipopolysaccharide (LPS) challenges was not affected by pretreatment with growth hormone. However, growth hormone treatment before LPS resulted in an increase in constitutive NOS activity, the phosphorylation of NOS3, plasma NOx levels and liver protein nitration, in growth hormone-treated compared with nongrowth hormone-treated animals. Of interest, the progressive increase in tissue CAT-2 mRNA after LPS was significantly reduced with growth hormone treatment in this model [42], potentially contributing to substrate limitation for NOS. Although not yet studied in $\mathrm{CF}$, these studies may suggest that growth hormone therapy in $\mathrm{CF}$ patients could have significant effects on NO formation by affecting the expression of NOS2 and by reducing L-arginine availability for NOS.

Low airway NO concentration may not only reflect decreased production but may also result from the reaction of $\mathrm{NO}$ with reactive oxygen species (ROS). Activated NOS can release ROS, such as the superoxide anion and hydrogen peroxide at nonsaturating L-arginine levels [43, 44], and NOS can generate $\mathrm{NO}$ and superoxide anion at the same time at low-saturating Larginine levels [45]. These products may react to generate peroxynitrite and subsequently result in tyrosine nitration. Nitrotyrosine had been previously found to be increased in $\mathrm{CF}$ lung tissue, sputum and exhaled breath condensate [46]. Previous studies had suggested that exogenous growth hormone primes human and rat neutrophils, monocytes and macrophages for a respiratory burst and an accompanying increase in superoxide production $[47,48]$. In contrast, NO release by cultured endothelial cells treated with growth hormone was only increased at growth hormone concentrations high enough to also result in a significant reduction of ROS formation. At lower concentrations, the expression of NOS3 was increased but $\mathrm{NO}$ was metabolised by reaction with ROS [20]. Therefore, the effect of growth hormone on NO production may be dose dependent, and higher doses than those used in the present study may potentially have different effects on pulmonary NO production.

In summary, the results of the present study suggest that treatment with human growth hormone results in decreased airway nitric oxide formation in patients with cystic fibrosis. Further studies are needed to clarify whether this observation is specific for cystic fibrosis and to specify the pathophysiological consequences of the observed changes in the L-arginine/nitric oxide metabolic pathway.

\section{ACKNOWLEDGEMENTS}

The authors would like to thank M. Groch and B. Cirkel (Children's Hospital, University of Duisburg-Essen, Essen, Germany) for their excellent technical assistance.

\section{REFERENCES}

1 Ratjen F, Döring G. Cystic fibrosis. Lancet 2003; 361: 681-689.

2 Grasemann H, Schwiertz R, Grasemann C, Vester U, Racke K, Ratjen F. Decreased systemic bioavailability of L-arginine in patients with cystic fibrosis. Respir Res 2006; 7: 87.

3 Kelly TJ, Drumm ML. Inducible nitric oxide synthase expression is reduced in cystic fibrosis murine and human airway epithelial cells. J Clin Invest 1998; 102: 1200-1207.

4 Meng QH, Springall DR, Bishop AE, et al. Lack of inducible nitric oxide synthase in bronchial epithelium: a possible mechanism of susceptibility to infection in cystic fibrosis. J Pathol 1998; 184: 323-331.

5 Moeller A, Horak F Jr, Lane C, et al. Inducible NO synthase expression is low in airway epithelium from young children with cystic fibrosis. Thorax 2006; 61: 514-520.

6 Ho LP, Innes JA, Greening AP. Exhaled nitric oxide is not elevated in the inflammatory airways diseases of cystic fibrosis and bronchiectasis. Eur Respir J 1998; 12: 1290-1294.

7 Grasemann H, Lax H, Treseler JW, Colin AA. Dornase $\alpha$ and exhaled NO in cystic fibrosis. Pediatr Pulmonol 2004; 38: 379-385.

8 Texereau J, Marullo S, Hubert D, et al. Nitric oxide synthase 1 as a potential modifier gene of decline in lung function in patients with cystic fibrosis. Thorax 2004; 59: 156-158.

9 Grasemann H, Knauer N, Büscher R, Hübner K, Drazen JM, Ratjen F. Airway nitric oxide levels in cystic fibrosis patients are related to a polymorphism in the neuronal nitric oxide synthase gene. Am J Respir Crit Care Med 2000; 162: 2172-2176.

10 Grasemann H, Storm van's Gravesande K, Büscher R, et al. Endothelial nitric oxide synthase variants in cystic fibrosis lung disease. Am J Respir Crit Care Med 2003; 167: 390-394.

11 Hopkins N, Gunning Y, O'Croinin DF, Laffey JG, McLoughlin P. Anti-inflammatory effect of augmented nitric oxide production in chronic lung infection. J Pathol 2006; 209: 198-205. 
12 Mhanna MJ, Ferkol T, Martin RJ, et al. Nitric oxide deficiency contributes to impairment of airway relaxation in cystic fibrosis mice. Am J Respir Cell Mol Biol 2001; 24: 621-626.

13 Lin WT, Yang SC, Chen KT, Huang CC, Lee NY. Protective effects of L-arginine on pulmonary oxidative stress and antioxidant defenses during exhaustive exercise in rats. Acta Pharmacol Sin 2005; 26: 992-999.

14 Grasemann H, Gärtig SS, Wiesemann HG, Teschler H, Konietzko N, Ratjen F. Effect of L-arginine infusion on airway NO in cystic fibrosis and primary ciliary dyskinesia syndrome. Eur Respir J 1999; 13: 114-118.

15 Grasemann H, Grasemann C, Kurtz F, Tietze-Schillings G, Vester U, Ratjen F. Oral L-arginine supplementation in cystic fibrosis patients: a placebo-controlled study. Eur Respir J 2005; 25: 62-68.

16 Grasemann H, Kurtz F, Ratjen F. Inhaled L-arginine improves exhaled nitric oxide and pulmonary function in patients with cystic fibrosis. Am J Respir Crit Care Med 2006; 174: 208-212.

17 Ricciardolo FL, Sterk PJ, Gaston B, Folkerts G. Nitric oxide in health and disease of the respiratory system. Physiol Rev 2004; 84: 731-765.

18 Karpuzoglu E, Fenaux JB, Phillips RA, Lengi AJ, Elvinger F, Ansar Ahmed S. Estrogen up-regulates inducible nitric oxide synthase, nitric oxide, and cyclooxygenase- 2 in splenocytes activated with $\mathrm{T}$ cell stimulants: role of interferon- $\gamma$. Endocrinology 2006; 147: 622-671.

19 Wickman A, Jonsdottir IH, Bergstrom G, Hedin L. GH and IGF-I regulate the expression of endothelial nitric oxide synthase (eNOS) in cardiovascular tissues of hypophysectomized female rats. Eur J Endocrinol 2002; 147: 523-533.

20 Thum T, Tsikas D, Frolich JC, Borlak J. Growth hormone induces eNOS expression and nitric oxide release in a cultured human endothelial cell line. FEBS Lett 2003; 555: 567-571.

21 Doi SQ, Jacot TA, Sellitti DF, et al. Growth hormone increases inducible nitric oxide synthase expression in mesangial cells. J Am Soc Nephrol 2000; 11: 1419-1425.

22 Inoue Y, Copeland EM, Souba WW. Growth hormone enhances amino acid uptake by the human small intestine. Ann Surg 1994; 219: 715-722.

23 Iannoli P, Miller JH, Sax HC. Epidermal growth factor and human growth hormone induce two sodium-dependent arginine transport systems after massive enterectomy. J Parenter Enteral Nutr 1998; 22: 326-330.

24 Rosen T, Bengtsson BA. Premature mortality due to cardiovascular disease in hypopituitarism. Lancet 1990; 336: 285-288.

25 Boger RH, Skamira C, Bode-Boger SM, Brabant G, von zur Muhlen A, Frolich JC. Nitric oxide may mediate the hemodynamic effects of recombinant growth hormone in patients with acquired growth hormone deficiency. A double-blind, placebo-controlled study. J Clin Invest 1996; 98: 2706-2713.

26 Schnabel D, Grasemann C, Staab D, Wollmann H, Ratjen F, the German CF Growth Hormone Study Group. A multicenter, randomized, double-blind, placebo-controlled trial to evaluate the metabolic and respiratory effects of growth hormone in children with cystic fibrosis. Pediatrics 2007; 119: e1230-e1238.
27 Hardin DS, Adams-Huet B, Brown D, et al. Growth hormone treatment improves growth and clinical status in prepubertal children with cystic fibrosis: results of a multicenter randomized controlled trial. J Clin Endocrinol Metab 2006; 91: 4925-4929.

28 Hardin DS, Ahn C, Prestidge C, Seilheimer DK, Ellis KJ. Growth hormone improves bone mineral content in children with cystic fibrosis. J Pediatr Endocrinol Metab 2005; 18: 589-595.

29 Braman RS, Hendrix SA. Nanogram nitrite and nitrate determination in environmental and biological materials by vanadium (III) reduction with chemiluminescence detection. Anal Chem 1989; 61: 2715-2718.

30 Baraldi E, de Jongste JC. Measurement of exhaled nitric oxide in children, 2001. Eur Respir J 2002; 20: 223-237.

31 ATS/ERS Recommendations for standardized procedures for the online and offline measurement of exhaled lower respiratory nitric oxide and nasal nitric oxide. Am J Respir Crit Care Med 2005; 171: 912-930.

32 Morris CR, Poljakovic M, Lavrisha L, Machado L, Kuypers FA, Morris SM Jr. Decreased arginine bioavailability and increased serum arginase activity in asthma. Am J Respir Crit Care Med 2004; 170: 148-153.

33 Lee J, Ryu H, Ferrante RJ, Morris SM Jr, Ratan RR. Translational control of inducible nitric oxide synthase expression by arginine can explain the arginine paradox. Proc Natl Acad Sci USA 2003; 100: 4843-4848.

34 El-Gayar S, Thuring-Nahler H, Pfeilschifter J, Rollinghoff M, Bogdan C. Translational control of inducible nitric oxide synthase by IL-13 and arginine availability in inflammatory macrophages. J Immunol 2003; 171: 4561-4568.

35 Kurz S, Harrison DG. Insulin and the arginine paradox. J Clin Invest 1997; 99: 369-370.

36 Jones KL, Hegab AH, Hillman BC, et al. Elevation of nitrotyrosine and nitrate concentrations in cystic fibrosis sputum. Pediatr Pulmonol 2000; 30: 79-85.

37 Grasemann H, Ioannidis I, Tomkiewicz RP, de Groot H, Rubin BK, Ratjen F. Nitric oxide metabolites in cystic fibrosis lung disease. Arch Dis Child 1998; 78: 49-53.

38 Morris CR, Kato GJ, Poljakovic M, et al. Dysregulated arginine metabolism, hemolysis-associated pulmonary hypertension, and mortality in sickle cell disease. JAMA 2005; 294: 81-90.

39 Yoon SS, Coakley R, Lau GW, et al. Anaerobic killing of mucoid Pseudomonas aeruginosa by acidified nitrite derivatives under cystic fibrosis airway conditions. J Clin Invest 2006; 116: 436-446.

40 Zheng S, Xu W, Bose S, Banerjee AK, Haque SJ, Erzurum SC Impaired nitric oxide synthase-2 signaling pathway in cystic fibrosis airway epithelium. Am J Physiol Lung Cell Mol Physiol 2004; 287: L374-L381.

41 Sekine N, Fukumoto S, Ishikawa T, Okazaki T, Fujita T. GH inhibits interferon- $\gamma$-induced signal transducer and activator of transcription- 1 activation and expression of the inducible isoform of nitric oxide synthase in INS-1 cells. Endocrinology 2001; 142: 3909-3916.

42 Elsasser TH, Kahl S, MacLeod C, Nicholson B, Sartin JL, Li C. Mechanisms underlying growth hormone effects in augmenting nitric oxide production and protein tyrosine nitration during endotoxin challenge. Endocrinology 2004; 145: 3413-3423. 
43 Stuehr D, Pou S, Rosen GM. Oxygen reduction by nitric oxide synthases. J Biol Chem 2001; 276: 14533-14536.

44 Heinzel B, John M, Klatt P, Bohme E, Mayer B. $\mathrm{Ca}^{2+} /$ calmodulin-dependent formation of hydrogen peroxide by brain nitric oxide synthase. Biochem J 1992; 281: 627-630.

45 Xia Y, Dawson VL, Dawson TM, Snyder SH, Zweier JL. Nitric oxide synthase generates superoxide and nitric oxide in arginine-depleted cells leading to peroxynitritemediated cellular injury. Proc Natl Acad Sci USA 1996; 93: 6770-6774.
46 Morrissey BM, Schilling K, Weil JV, Silkoff PE, Rodman DM. Nitric oxide and protein nitration in the cystic fibrosis airway. Arch Biochem Biophys 2002; 406: 33-39.

47 Warwick-Davies J, Lowrie DB, Cole PJ. Growth hormone is a human macrophage activating factor. Priming of human monocytes for enhanced release of $\mathrm{H}_{2} \mathrm{O}_{2}$. J Immunol 1995; 154: 1909-1918.

48 Spadoni GL, Spagnoli A, Cianfarani S, et al. Enhancement by growth hormone of phorbol diester-stimulated respiratory burst in human polymorphonuclear leukocytes. Acta Endocrinol (Copenh) 1991; 124: 589-594. 